Acta Universitatis Nicolai Copernici • Pedagogika XXXIV/2/2017

Nauki Humanistyczno-Społeczne • Zeszyt 440

DOI: http://dx.doi.org/10.12775/AUNC_PED.2017.016

Piotr Krakowiak

Uniwersytet Mikołaja Kopernika w Toruniu

\title{
Praca socjalna w Szkocji WOBEC ZAGROŻEŃ DZIECI W ŚRODOWISKU LOKALNYM \\ (Na przykładzie instytucji wskazanej osoby - named person)
}

\section{Wprowadzenie}

Doszukując innowacyjnych metod i narzędzi, związanych ze wsparL ciem dzieci i młodzieży dotkniętych kryzysem ciężkiej choroby i śmierci bliskiej osoby, napotkałem w systemach pomocowych i w pracy socjalnej w Szkocji kilka interesujących metod współpracy różnych podmiotów ekonomii społecznej oraz tworzenia sieci pomocy i wsparcia $^{1}$. Niektóre z nich już doczekały się adaptacji na język polski i są narzędziami wykorzystywanymi w pomocy dzieciom i młodzieży w żałobie ${ }^{2}$,

1 All-Ireland Institute of Hospice and Palliative Care, www. childrenspalliativehub. com/palliative-journey/end-life-care uk (dostęp: grudzień 2016).

2 Dobre praktyki wiodącej w UK organizacji wspierającej dzieci i młodzież w żałobie - Winston Wish - www. winstonswish.org.uk, zostały wykorzystane w przygotowaniu i prowadzeniu przez Fundację Hospicyjną polskiej strony wspierającej dzieci i młodzież w żałobie - http://tumbopomaga. pl (dostęp: grudzień 2016). 
zdobywając pozytywne opinie pedagogów ${ }^{3}$. Kolejne ciekawe inicjatywy, które staną się w przyszłości przedmiotem moich analiz naukowych i adaptacji w obszarze pedagogiki społecznej i pracy socjalnej, dotyczyć będą pomocy po stracie, a także wsparcia w żałobie oferowanego poprzez organizacje pozarządowe we współpracy z instytucjami pomocowymi i środowiskiem lokalnym w krajach anglosaskich ${ }^{4}$. Współpraca systemu pomocy społecznej z instytucjami opieki zdrowotnej, a także innymi organizacjami w środowisku lokalnym była jednym z postulatów mojej publikacji, zakończonej imperatywem dla badaczy i praktyków, by poszukiwać konkretnych form współdziałania 5 . Tropem właściwym dla realizacji tych poszukiwań wydał mi się dokument wydany przez szkocki rząd, dotyczący współpracy pomocy społecznej i ochrony zdrowia w trosce o dzieci i młodzież w środowisku lokalnym. Był owocem działań ekspertów ekonomii społecznej, pracy socjalnej i edukacji ${ }^{6}$, a efekt ich pracy został opisany i wydany w 2012 r. w formie książkowej jako zapowiedź programu

Analiza tego dokumentu i kolejnych kroków związanych z poszukiwaniem sposobu współpracy różnych środowisk z dziećmi i młodzieżą zagrożonymi wielorakimi kryzysami doprowadziła mnie do rozważań niezwiązanych bezpośrednio z moją tematyką badawczą, ale wartych uwagi z powodu próby integracji i koordynacji działań oraz niespodziewanych konsekwencji projektu w fazie jego implementacji. Sądzę, że zaprezentowane treści, nieznane dotychczas w Polsce, pozwolą teoretykom wychowania, badaczom i praktykom pracy socjalnej i działań pomocowych zrozumieć, jak ważne jest, by w podejmowanych działaniach zadbać zarówno o bezpieczeństwo dzieci i młodzieży, jak i o udział w tym procesie wszystkich zaangażowanych osób i instytucji.

3 Por. tumbopomaga. pl/dla-nauczycieli pl: tumbopomaga.pl/images/pdf/ Nauczyciele_spolecznoscszkolna_a. pdf (dostęp: grudzień 2016).

4 Por. Scotland's Bereavement Charity, www.crusescotland.org.uk (dostęp: grudzień 2016).

${ }^{5}$ Por. P. Krakowiak, Wolontariat $w$ opiece u kresu życia, Toruń 2012.

6 Scottish Families website is funded by the Scottish Government, www.scottishfamilies.gov.uk (dostęp: grudzień 2016).

7 Getting it right for every child (GIRFEC), http://www.gov. scot/Topics/People/Young-People/gettingitright (dostęp: grudzień 2016). 


\section{Szkocka propozycja współpracy pomocy społecznej, ochrony zdrowia i szkół w środowisku lokalnym na rzecz dzieci i młodzieży - geneza „Getting it Right for Every Child” (GIRFEC)}

Badanie szkockiego projektu włączającego systemy opieki społecznej i zdrowia do edukacji ułatwiło mi opracowanie przygotowane przez polską przedstawicielkę europejskiego think tanku, monitorującego systemy edukacyjne na naszym kontynencie. Skrót opracowania Aleksandra Styś w języku angielskim, dostępnego jako otwarte źródło wiedzy w wersji elektronicznej, pomoże opisać ten proces w szkockim społeczeństwie i w systemach pomocy społecznej i edukacji ${ }^{8}$.

Projekt Getting it Right for Every Child (GIRFEC, „Właściwa opieka dla każdego dziecka"), zapoczątkowany został w 2006 r. jako program dla dzieci w Szkocji. To holistyczne podejście wdrożeniowe zostało oparte na przekonaniu, iż umożliwienie wszystkim dzieciom rozwoju, aż do osiągnięcia pełni ich potencjału, będzie możliwe przez współdziałanie rożnych osób i instytucji. GIRFEC postawiło sobie za cel zmianę kultury działających systemów i istniejących praktyk, podkreślając znaczenie wspólnej odpowiedzialności wszystkich, w tym ochrony zdrowia, przedszkoli i szkół, ośrodków wspierania rodzin, usługodawców pracy socjalnej, wspólnot mieszkaniowych i innych podmiotów w lokalnej wspólnocie ${ }^{9}$. Zdaniem specjalistów badających ten projekt przyjęta strategia wczesnej interwencji miała usprawnić ewidencję usług dla dzieci, a także implementację planów działania $\mathrm{w}$ oparciu o istniejące narzędzia treningowe, metody poradnictwa

8 Por. A. Styś, Getting it Right for Every Child (GIRFEC), za: European Institute of Education and Social Policy, www.eiesp.org/site/pages/view/123-getting-it-right-for-every-child-girfec-aleksandra-sty.html (dostęp: grudzień 2016). Kolejna część artykułu będzie skrótem tego tekstu z autorskim tłumaczeniem na język polski.

9 Por. Scottish Government (2012). A Guide to Getting it Right for Every Child. Edinburgh. Retrieved from http://www.gov.scot/Resource/0045/00458341.pdf (dostęp: grudzień 2016). 
i przy użyciu zasobów elektronicznych, które ułatwią wymianę informacji wśród zaangażowanych osób i podmiotów ${ }^{10}$.

Jak zauważa w swoim raporcie Styś, wprowadzenie projektu GIRFEC było konsekwencją reformy systemu ochrony dzieci w Szkocji, rozpoczętej w 2002 r. od badania i przeglądu systemu ochrony praw dziecka. W jego następstwie szkocki rząd opublikował raport, w którym wskazano szereg dobrych praktyk współpracy, podkreślając, że nie wszystkie szkockie dzieci otrzymują odpowiednią opiekę i ochronę. W 2004 r. został przeprowadzony szczegółowy przegląd systemu, który wykazał potrzebę znaczącej reformy i poprawy usług na rzecz dzieci wymagających społecznego wsparcia i pomocy. Badający problematykę badacze z Uniwersytetu w Glasgow zwrócili w swoim doniesieniu uwagę, że pojawiła się wola opracowania nowych rozwiązań, zachęcających odmienne obszary szkockiego społeczeństwa do współpracy, aby osiągnąć jak najlepsze rezultaty. Ich zdaniem GIRFEC odzwierciedlała filozofię całego cyklu wcześniejszych wydarzeń ${ }^{11}$. Można zatem uznać proces kilkunastu lat badań, namysłu i kolejnych praktycznych kroków, mających na celu integrację wsparcia zagrożonych dzieci i młodzieży w Szkocji, za wystarczający, by rozpocząć implementację nowych działań, które zostaną opisane dalej.

\section{Praktyczna implementacja współpracy poprzez instytucję wskazanej osoby - named person}

Długoletni proces wprowadzania instytucji wskazanej osoby (named person) do poprawy opieki nad zagrożonymi dziećmi i młodzieżą w Szkocji miał swoją kilkuletnią fazę pilotażową, rozpoczętą po publikacji pierwotnego planu GIRFEC w czerwcu 2006 r. Inicjatywa Highland Pathfinder została uruchomiona w celu przetestowania w praktyce zasady GIRFEC i przygotowania w oparciu o uzyskane wyniki wytycznych krajowych oraz wskazanie dobrych praktyk na przy-

10 Por. A. Stafford, S. Vincent, N. Parton (eds.), Child Protection Reform across the United Kingdom, Edinburg 2010.

11 Por. A. Styś, dz. cyt. 
szłość. Inicjatywa wspierana przez naukowców z Aldgate i Rose Open University w latach 2006-2009 pozwoliła na zaplanowanie, analizę i przegląd możliwych działań dla wszystkich zaangażowanych osób i agencji, niezależnie od ich doświadczenia zawodowego ${ }^{12}$. Krajowa praktyka modelu GIRFEC została poprzez te pilotażowe badania ukierunkowana na opracowanie planu dla każdego dziecka w procesie edukacyjnym lub opiekuńczym w Szkocji. Instytucję wskazanej osoby uznano za nowe narzędzie, które może być wykorzystane wraz z innymi narzędziami oceny potrzeb dzieci i młodzieży zagrożonych różnego rodzaju kryzysami.

Po badaniu pilotażowym przygotowano ogólnokrajową praktykę (National Practice Model), zawierającą cztery główne etapy ${ }^{13}$. Pierwszy jest związany z wykorzystaniem wskaźników dobrego samopoczucia, badanych w opisie „kręgu dobrostanu” (Well-being Wheel). Dotyczy on udostępniania informacji, mogących wskazywać na konieczność troski i wczesnej interwencji, jeśli to możliwe. Po drugie, w celu zrozumienia szerszego obrazu świata dziecka praktycy opieki odnoszą się do „trójkąta mojego świata” (My World Triangle), który jest pomocny w identyfikacji potrzeb i zagrożeń. Trzeci etap odnosi się do bardziej skomplikowanych przypadków i pozwala praktykom na wykorzystanie narzędzia „matrix wytrzymałości” (Resilience Matrix). Pomaga ono uporządkować i przeanalizować niezbędne informacje w sytuacji kryzysowej. Gdy wszystkie potrzeby dziecka lub młodej osoby zostaną zidentyfikowane, może zostać nakreślony krąg podsumowany, jako pożądany poziom dobrostanu dziecka, pozwalający zaprojektować konkretny plan działań ${ }^{14}$. W analizie przedstawicielki europejskiej organizacji pozarządowej GIRFEC stanowi „ekologiczny” i rozwojowy model w praktyce uznający znaczenie zaspokojenia po-

12 Por. Scottish Government (2010b). Getting it right for every child and young person (Getting it right): A framework for measuring children's well-being, http:// www.gov.scot/Resource/0039/00398541. pdf (dostęp: grudzień 2016).

13 National Practice Model, Figure 1, Scottish Government, A Guide to Getting it Right for Every Child. Edinburgh, 2010: http://www.gov.scot/Resource/0045/00458341.pdf (dostęp: grudzień 2016).

${ }^{14}$ Por. Scottish Government, A Guide to Getting it Right for Every Child. 
trzeb całościowych (holistycznych) dziecka. Zamiast pojedynczej roli, którą odgrywają podopieczni (np. członek rodziny, pacjent, uczeń, ofiara lub młody przestępca), ocena GIRFEC stara się zidentyfikować wszystkie czynniki, które mogą mieć zarówno pozytywne, jak i negatywne konsekwencje dla dobrostanu dziecka. Taki system może pomóc w znalezieniu najbardziej efektywnych rozwiązań problemów, które podopieczni mogą napotkać w ich życiu15.

\section{Elementy i perspektywy implementacji projektu wyznaczonej osoby (named person) w strukturze społeczności lokalnej i profesjonalistów}

Pozytywnie oceniony przez szkockie władze, jak również przez europejskie organizacje monitorujące tego typu działania, projekt GIRFEC składa się z 10 podstawowych elementów:

- nacisku na poprawę wyników dla dzieci, młodzieży i ich rodzin w oparciu o wspólne zrozumienie dobrego samopoczucia;

- wspólnego podejścia do uzyskania zgody oraz do wymiany informacji w stosownych przypadkach;

- zaznaczenia roli dzieci, młodzieży i ich rodzin w zakresie oceny, planowania i interwencji;

- skoordynowania i ujednolicenia podejścia do identyfikacji problemów, oceny potrzeb oraz uzgodnienia działań i wyników w oparciu o wskaźniki dobrego samopoczucia;

- uproszczonego planowania, oceny i podejmowania decyzji co do procesów, które prowadzą do właściwej pomocy w odpowiednim czasie;

- spójnych wysokich standardów współpracy i komunikacji, w których bierze udział więcej niż jedna agencja, lokalnie i całej Szkocji;

- wyznaczenie osoby imiennie dla każdego dziecka i młodego człowieka, a także wiodący profesjonalista (jeśli to konieczne), aby koordynować i monitorować działanie wielu agencji;

15 A. Styś, dz. cyt. 
- maksymalizacji wykwalifikowanej siły roboczej w ramach usług powszechnych do potrzeb i określenia ryzyka;

- kompetencji pracowników we wszystkich usługach dla dzieci, młodzieży i ich rodzin;

- zdolności do oceny i planowania informacji - w tym elektronicznie - wewnątrz i poza biurem ${ }^{16}$.

Pomijając głębsze analizy, na potrzeby tego artykułunależy zaznaczyć, iż wszystkie elementy opierają się na zestawie uniwersalnych wartości i zasad, które obejmują umieszczenie dziecka w centrum uwagi poprzez słuchanie jego opinii i angażowanie je do podejmowania decyzji dotyczących jego życia. Biorąc pod uwagę całą historię życia dziecka i jej konsekwencje, ważne jest uznanie znaczenia wewnętrznego głosu dziecka w każdych okolicznościach. Promowanie wartości, ze szczególnym naciskiem na postawy szacunku, cierpliwości, uczciwości, rzetelności, uczciwości i odporności wśród wszystkich dzieci, młodzieży, ich rodzin i współpracowników ${ }^{17}$.

Styś w swojej publikacji przedstawia perspektywy implementacji projektu GIRFEC. Szkoccy decydenci wskazali, że zmiana będzie wprowadzana stopniowo i wymaga czasu. Jednym z największych wyzwań $\mathrm{w}$ procesie wdrażania jest praktyczne wykonanie założeń, ponieważ współpraca, łatwa na papierze, w rzeczywistości jest bardzo trudna. Istnieją różne godziny pracy i poszczególne zawody reprezentują różne nastawienie do problemów. Trudność stanowi też uczucie frustracji i niepokoju wśród nauczycieli ze względu na rosnącą liczbę zmian w edukacji, które z kolei nie zawsze pozostawiają im wystarczająco dużo czasu i przestrzeni do wymiany doświadczeń z innymi profesjonalistami ${ }^{18}$. Specjaliści ze Szkocji widzą w GIRFEC swoisty katalizator poprawy multidyscyplinarnej oceny i wspólnych planów działań, kon-

16 Scottish Government, A Guide to Getting it Right for Every Child.

17 Por. Scottish Government, Changing Professional Practice and Culture to Get it Right for Every Child: An Evaluation of the Development and Early Implementation Phases of Getting it right for every child in Highland: 2006-2009, Edinburgh 2009, http://www. gov. scot/resource/doc/292706/0090352. pdf (dostęp: grudzień 2016).

18 A. Styś, dz. cyt. 
centrujących się na wszystkich aspektach życia dziecka i zwiększeniu dostępu do usług. Dzięki GIRFEC dla jednego dziecka ze złożonymi potrzebami i różnymi agencjami wsparcia powstanie jeden plan działania oraz zespół działający razem i na podstawie wspólnego porozumienia wszystkich jego potrzeb ${ }^{19}$. Zarówno specjaliści rządowi, naukowcy, jak i europejscy obserwatorzy widzieli przede wszystkim dobre strony opisywanego projektu, jednak oddolne inicjatywy społeczne i profesjonalne wykazały jego braki, co zostanie przedstawione w konkluzji tego artykułu, jako ostrzeżenie dla naukowców i praktyków zajmujących się nowymi formami wsparcia zagrożonych dzieci i młodzieży w Polsce.

\section{Reakcja na implementację projektu „Getting it Right for Every Child" (GIRFEC) jako zagrożenie ze strony named person dla rodzin, instytucji edukacyjnych, pomocowych i społeczeństwa}

Polityka wskazanej osoby od lat była ważną częścią polityki społecznej wobec dzieci i młodzieży w Szkocji, starającej się zapewnić możliwość działania, gdy rodzinna sytuacja dzieci jest trudna. Propozycja została przyjęta po głosowaniu parlamentu szkockiego w czerwcu 2016 r., choć wcześniej były już negatywne głosy na jej temat od grup osób i profesjonalistów. Ich opinie zostały zebrane na portalu internetowym, który już swoją nazwą wyraża sprzeciw wobec tej propozycji - no2np.org ${ }^{20}$. Pozostawiając szczegółową analizę dokumentów zainteresowanym, przedstawię 11 głównych tez przeciwników wprowadzenia projektu w Szkocji, opublikowanych jako broszura ogólnodostępna w przestrzeni wirtualnej ${ }^{21}$ :

19 Por. A. S. Robertson, Child Welfare Assessment Practices in Scotland: An Ecological Process Grounded in Relationship-Building, "Journal of Public Child Welfare" No 8(2), 2014, p. 164-189.

20 Zainteresowanych szczegółowym przebiegiem debaty społecznej i całej historii oddolnego ruchu sprzeciwu odsyłam do bazy dokumentów dostępnej pod adresem: http://no2np.org/resources/.

21 http://no2np.org/wp-content/uploads/no2np_11reasons.pdf (dostęp: grudzień 2016) 
1. Twojemu dziecku zostanie przyznana wskazana osoba - czy tego chcesz czy nie.

2. Wskazana osoba będzie stać na straży „dobrostanu” (well-being) twojego dziecka.

3. Czy „dobrostan” dziecka koniecznie oznacza jego szczęście?

4. Wskazana osoba będzie współrodzicem i sprawdzać będzie twoją wydolność wychowawczą.

5. Wskazana osoba będzie posiadała i udostępniała prywatne informacje dotyczące dziecka i rodziny.

6. Wskazana osoba będzie mogła usłyszeć o problemach dziecka, o których nie wiedzą i nie usłyszą rodzice.

7. Jeśli się nie zaangażujesz (w GIRFEC), będziesz na czarnej liście.

8. Ci, którzy faktycznie potrzebują pomocy, zostaną pominięci.

9. Przedstawiciele opieki zdrowotnej i nauczyciele są już dostatecznie zajęci (a w projekcie GIRFEC named person to oni mieliby być wskazanymi osobami - w przypadku szkoły byłoby to kilkadziesiąt dzieci dla jednej wskazanej osoby).

10. Programy pilotażowe mówią o wielkim sukcesie tej metody, ale tak twierdzą tylko jej zwolennicy.

11. Wielu z tych, którzy działali w systemie GIRFEC, nie wiedziało, z czym się wiąże jego istota ${ }^{22}$.

Współpraca rodziców niegodzących się na działania pomijające rodziny, ale także instytucji edukacyjnych, związków wyznaniowych i wielu innych organizacji, okazała się w praktyce zintegrowana w wyrażeniu sprzeciwu wobec projektu pełnego wątpliwości co do jego implementacji. Pomijając przebieg społecznej debaty, warto zauważyć, iż długoletni projekt rządowy został ostatecznie oceniony przez Sąd Najwyższy Wielkiej Brytanii, który wydał wyrok w lipcu 2016 r. ${ }^{23}$ W historycznym werdykcie pięciu najwyższych rangą sędziów w Wielkiej Brytanii (w tym dwóch Szkotów) jednogłośnie uchyliło decyzję sądu z Edynburga w sprawie legalności instytucji Wskazanej Osoby

22 Tłumaczenie i wybór autorskie, całość dostępna w języku angielsku: http://no2np.org/resources/ (dostęp: grudzień 2016).

23 Por. https://www. supremecourt. uk/cases/docs/uksc-2015-0216-presssummary. pdf (dostęp: grudzień 2016). 
dla Dzieci i Młodzieży (Named Person provisions of the Children and Young People Scotland Act 2014). Sędziowie określili badane prawo jako „wadliwe” z powodu naruszenia art. 8 Europejskiej konwencji praw człowieka (EKPC), gwarantującego „prawo do życia prywatnego i rodzinnego" każdej rodziny. Oświadczyli również, że rząd Szkocji przekroczył swoje uprawnienia poprzez ustawę, która pozwalała organom publicznym na udzieleniepoufnych informacji na temat dzieci i rodziców bez ich zgody ${ }^{24}$.

Na koniec warto zauważyć, co rzecznik społecznego ruchu NO2NP, Simon Calvert, powiedział po ogłoszeniu werdyktu: „Jesteśmy bardzo zadowoleni z decyzji, która potwierdziła nasze obawy, gdyż 35000 osób, które podpisały naszą petycję, zostały prawidłowo zrozumiane. Proponowany system był nachalny, niezrozumiały i niezgodny z prawem. Dobrze, że ten instytucjonalny Big Rother to już historia"25.

\section{Zakończenie}

Tak jak autor, z pewnością wszyscy czytelnicy zgodzą się z opinią, iż integracja działań pomocowych jest niezbędna, podobnie jak intensyfikacja współpracy dla dobra dziecka. Jak jednak widać w przeanalizowanym przykładzie ze Szkocji, procesy integracyjne nie mogą być narzucone odgórnie. Pomimo długiego okresu studiów i pilotażowych wdrożeń pominięte $\mathrm{w}$ procesie osoby i instytucje mogą zakwestionować jej zasadność i skuteczność. Zarówno w przypadku rodzin nierozumiejących roli named person w strukturze społecznej, jak i w przypadku opiekunów z ochrony zdrowia, sprawujących pieczę nad małymi dziećmi, czy nauczycieli dzieci i młodzieży w wieku szkolnym, opór przed kolejnymi obowiązkami wykluczył ich właściwą rolę $\mathrm{w}$ integracji planowanych działań ${ }^{26}$.

${ }^{24}$ http://no2np.org/victory-supreme-court-strikes-named-person-scheme/ (dostęp: grudzień 2016)

25 Tamże.

26 http://www.unison-scotland.org/2016/01/13/health-visitor-survey/ (dostęp: grudzień 2016) 
Zamiast mnożenia instytucjonalnych form opieki i wyznaczania opiekunów na każdym z możliwych poziomów, praca nad przywróceniem współdziałania pomiędzy osobami, rodzinami i instytucjami pomocowymi oraz szkołą powinna być strategicznym planem działania dla środowisk lokalnych w Szkocji ${ }^{27}$. W polskim społeczeństwie i w środowiskach lokalnych, w których wartość rodziny jest ostatnio wielokrotnie podkreślana, a formalnie została podniesiona do rangi priorytetu przez zmianę nazwy kluczowego ministerstwa ${ }^{28}$, powinniśmy zadbać o to, by uniknąć błędów popełnionych przez innych. Integracja i koordynacja działań powinna opierać się na dialogu społecznym, uznaniu racji każdej ze stron, czy grup współuczestniczących w projektach i wdrożeniach. W przypadku wielu działań edukacyjnych i pedagogicznych zachowanie tego warunku doprowadzi do poprawy skuteczności, co powinno być celem wszystkich osób i instytucji zatroskanych o pomoc osobom w kryzysach.

Dla mnie ta edukacyjna wycieczka w świat kryzysów dzieci i młodzieży oraz problemów z tożsamością instytucji named person w szkockiej rzeczywistości pomocowej jest przestrogą przed forsowaniem rozwiązań integracyjnych w obszarze opieki nad osobami u kresu życia $^{29}$ i opiekunów nieformalnych, szczególnie opiekunów rodzinnych. Świadomość wielu zmiennych w życiu rodzin dotkniętych tego rodzaju kryzysami, różnych w zależności od rodzaju schorzenia, może podobnie jak w analizowanym projekcie wsparcia dzieci w kryzysach, zakończyć się porażką, gdy ustawodawcy i badacze pominą etap konsultacji społecznych z każdą ze stron w celu znalezienia optymalnego rozwiązania. Mam nadzieję, że naukowcy i praktycy odnajdą w zaprezentowanym tekście przesłanie dla ich działań, niezależnie od rodzaju kryzysów, na które szukają odpowiedzi w swojej działalności.

27 http://no2np.org/resources/answers-common-arguments/ (dostęp: grudzień 2016)

28 Ministerstwo Rodziny, Pracy i Polityki Społecznej, https://www.mpips. gov.pl/ (dostęp: grudzień 2016).

29 Por. P. Krakowiak, dz. cyt. 


\section{Streszczenie}

\section{Praca Socjalna w SzKocjI WOBEC Zagrożeń DZIECI W ŚRODOWISKU LOKALNYM. (NA PRZYKŁADZIE INSTYTUCJI WSKAZANEJ OSOBY - NAMED PERSON)}

Dobre praktyki krajów europejskich w zakresie szeroko pojętej pracy socjalnej stanowić mogą źródło inspiracji do zmian w naszym rodzimym systemie wsparcia społecznego, jak również wskazać wielość perspektyw i spojrzeń społecznych na proponowane rozwiązania systemowe. Jednym z obszarów działania pracowników socjalnych jest troska o dzieci i młodzież w przypadku zagrożenia kryzysami. Przykładem podjętej w tym aspekcie współpracy pomocy społecznej i ochrony zdrowia w środowisku lokalnym może być szkocki program z 2012 roku - Getting it right for children \& families, uznający potrzebę współpracy wszystkich podmiotów działających w interesie ochrony dzieci przed nadużyciami. Jego dopełnieniem od 2014 roku stał się projekt Named Person (wskazana osoba), będący próbą poprawy wyników w zakresie wsparcia dzieci zagrożonych nadużyciami. Program ten powoływał instytucję wskazanej osoby, która w założeniu stać się miała rzecznikiem dziecka, stojącym na straży jego dobrostanu. Zaproponowana w artykule metaanaliza programu Named Person stanowi punkt wyjścia do refleksji na temat zakresu ingerencji instytucji w życie rodziny, będącej naturalnym obszarem troski i wychowania dziecka. Wnioski ze społecznej debaty w Szkocji mogą nas nauczyć, jakie konsekwencje nieść może brak wsparcia rodziny dla zwiększenia jej skuteczności wychowawczo-opiekuńczej na rzecz instytucjonalnego nadzoru lub zbyt dużej władzy danej opiekunom zewnętrznym. Instytucje edukacyjne i pomocowe $\mathrm{w}$ środowisku lokalnym powinny współpracować z rodzinami, realizując pracę socjalną w środowisku zamieszkania i w szkole.

Słow a kluczowe: dzieci i młodzież; interwencja kryzysowa; współpraca instytucji; GIRFEC; wskazana osoba 


\section{Summary}

\section{SOCIAL WORK IN SCOTLAND AGAINST DANGERS FACED}

BY CHILDREN IN THE LOCAL ENVIRONMENT

(USING THE EXAMPLE OF THE INSTITUTION OF THE NAMED PERSON)

The inspiration for the publication was a document issued by the Scottish Government regarding cooperation of social assistance and health care for the sake of children and youth in the local environment. It was the fruit of the activities of experts in social economy, social work and education, and the effect of their work was described as the program's announcement (www. scottishfamilies.gov.uk). The analysis will allow education theoreticians, researchers and practitioners to understand how important it is to ensure both the safety of children and young people, as well as the proper participation of all persons and institutions involved in the process. The text will start with the genesis of "The Getting it Right for Every Child project" (GIRFEC), through the pilot phase of the named person institution in Scotland, to the current responses to the named person's threat to families, educational and support institutions and society as a whole. The debate on this social support mechanism in Scotland continues and will demand another publication for Polish researchers and practitioners of social work in the future.

Keywords: children and adolescents; crisis intervention; cooperation of institutions; GIRFEC; named person 
